\title{
GAMBARAN PELAKSANAAN TUGAS KESEHATAN KELUARGA PADA KELUARGA YANG MEMILIKI LANSIA HIPERTENSI DI DESA GLAGAHWERO KECAMATAN PANTI KABUPATEN JEMBER
}

\author{
Indra Kurniawan ${ }^{1 *}$, Tri Buana Ratnasari ${ }^{2}$ \\ Fakultas Keperawatan, Universitas Jember \\ Jl. Kalimantan No.37 Kampus Tegal Boto Jember Telp./Fax (0331)323450 \\ *e-mail: indrak19.ik@gmail.com@yahoo.com
}

\begin{abstract}
The purpose of this study is to describe the implementation of family health functions that are old with hypertension. The design of this study is descriptive. The study was conducted on elderly families with hypertension in Glagahwero Village, Panti Sub-district, Jember District. The total sample was 8 people taken using the accidental sampling technique data collected by quetionnaire. The analysis used univariate analysis. The results show description Family Ability to perform high health tasks, 5 respondents (62.5\%). This means the description from Implementation of an elderly family health function with hypertension is high. The results of this study recommend forpublic health center services to improve information to the community, especially families with parents with hypertension.
\end{abstract}

Keywords: Elderly, family health task, elderly hypertension

\section{PENDAHULUAN}

Keberhasilan pemerintah dalam pembangunan nasional telah terwujud berbagai hasil yang positif di berbagai bidang terutama di bidang kesehatan yang dapat meningkatkan kualitas kesehatan penduduk, dan usia harapan hidup, sehingga jumlah penduduk yang berusia lanjut meningkat dan cenderung bertambah lebih cepat (Mubarak, Chayatin, \& Santoso, 2010). Usia lanjut adalah tahap akhir siklus kehidupan yang merupakan tahap perkembangan normal dan akan dialami oleh setiap individu dan merupakan kenyataan yang tidak dapat dihindari (Notoatmodjo, 2007). Menjadi tua melewati tiga tahap kehidupan yaitu anak, dewasa, dan tua. WHO dan Undang-Undang Nomor 13 tahun 1998 tentang kesejahteraan lanjut usia pada Bab 1 Pasal 1 Ayat 2 menyebutkan bahwa umur 60 tahun adalah usia permulaan tua (Nugroho, 2008). Penduduk berusia 60 tahun di dunia diprediksikan dapat mencapai angka lebih dari 1 milyar pada tahun 2020. Jumlah lansia di Amerika juga akan meningkat hingga $24 \%$ pada tahun 2050 (Friedman, Bowden, \& Jones, 2003). Menurut proyeksi WHO pada tahun 1995 bahwa tahun 2020 diperkirakan jumlah lansia di Indonesia pun sekitar 28 juta jiwa dan tahun 2050 dibandingkan dengan tahun 1990 pertumbuhan lansia Indonesia mengalami pertumbuhan terbesar di Asia yaitu sebesar $411 \%$, Thailand $337 \%$, India 242\%, dan China 220\% (Martono, 2011). Jumlah lansia di 
Indonesia tahun 2011 menurut Kementerian Kesehatan Republik Indonesia adalah lansia yang berusia 60-64 tahun sebanyak 5.901.728 jiwa, usia 65-69 tahun sebanyak 4.485.989 jiwa, usia 70-74 tahun sebanyak 3.087.132 jiwa dan usia 75 tahun keatas sebanyak 3.239.077 jiwa, sedangkan di Propinsi Jawa Timur pada tahun 2008 merupakan propinsi dengan peringkat kedua di Indonesia dengan jumlah lanjut usia terbanyak yaitu 3,2 juta jiwa setelah Propinsi Yogyakarta. Jumlah usia lanjut umur 60 tahun ke atas berdasarkan proyeksi penduduk sasaran program tahun 2013 sebanyak 277.398 orang, yang dilayani kesehatannya sebanyak 265.567 orang atau 95,73\%. Hal ini menunjukkan bahwa pelayanan lansia di Kabupaten Jember mengalami peningkatan drastis dibandingkan tahun 2012.

Gambaran 10 jenis penyakit utama tahun 2013 yang ada di seluruh puskesmas di kabupaten Jember pada tahun 2013 hipertensi menduduki peringkat kedua yaitu sebanyak 5,11\% dari total 1.368.475 kunjungan. Data dari puskesmas Panti dari 10 data kunjungan penyakit pada tahun 2017 hipertensi menduduki peringkat ke 5 dengan 810 kasus.

Hasil survei yang dilakukan peneliti pada masyarakat desa Glagahwero Kecamatan Panti didapatkan jumlah lansia sebanyak 679 orang, dari jumlah tersebut sebanyak 543 orang $(80,9 \%)$ mengalami masalah kesehatan hipertensi. Lansia mengalami berbagai gejala akibat penurunan kondisi fisik, psikologis, sosial dan ekonomi, hal ini akan berpengaruh terhadap seluruh aspek kehidupan lansia termasuk kesehatannya. Seiring dengan bertambahnya usia seseorang, berbagai permasalahan kesehatan mulai bermunculan.

Menurut Kementrian Kesehatan Republik Indonesia penyakitlanjut usia sering berbeda dengan dewasa muda, karena penyakit pada lansia merupakan gabungan dari kelainan-kelainan yang timbul akibat penyakit dan proses menua, yaitu proses menghilangnya secara perlahan kemampuan jaringan untuk memperbaiki diri atau mengganti diri serta mempertahankan struktur dan fungsi normalnya, sehingga tidak dapat bertahan terhadap penyakit (infeksi) dan memperbaiki kerusakan yang diderita. Keluhan kesehatan yang dialami oleh lansia merupakan efek dari penyakit kronis seperti asam urat, hipertensi, diabetes mellitus, rematik dan penyakit lainnya, dan yang merupakan penyakit penyebab rawat jalan tertinggi pada tahun 2010 yang dialami lansia adalah hipertensi.

Hipertensi merupakan penyakit degeneratif, dengan bertambahnya usia seseorang kemungkinan untuk menderita hipertensi juga semakin besar, hipertensi banyak ditemukan pada lanjut usia (Anggraeni, 2012).

Menurut WHO, tekanan darah dianggap normal bila kurang dari 135/85 mmHg, sedangkan bila lebih dari 140/90 mmHg dikatakan hipertensi. Batasan ini berlaku bagi orang dewasa di atas 18 tahun (Adib, 2009). Batasan tekanan darah untuk lansia adalah 160/90 $\mathrm{mmHg}$, jika tekanan darah lansia melebihi dari batas tersebut maka lansia menderita hipertensi (Fatimah, 2010).

Menurut Anggraeni penyebab hipertensi pada lansia salah satu faktor resikonya antara lain stress, faktor keturunan, usia, asupan garam dan gaya hidup yang kurang sehat. Organisasi kesehatan dunia (WHO) menetapkan hipertensi sebagai faktor 
resiko nomor tiga penyebab kematian di dunia (Ridwan, 2011). Insiden hipertensi pada lanjut usia cukup tinggi yaitu $40 \%$ dengan kematian 50\% diatas umur 60 tahun (Suhadi, 2011) Lansia yang mengalami penyakit kronis seperti hipertensi pada umumnya lebih memilih tinggal dilingkungan keluarga.

Menurut Tamher \& Noorkasiani (2011) keluarga merupakan tempat berlindung yang paling disukai para lansia. Lansia lebih memilih tinggal bersama keluarganya dari pada tinggal di institusi seperti panti jompo, terdapat sekitar $65 \%$ lansia yang mengidap gangguan kesehatan seperti penyakit kronik atau kecacatan, hidup bersama orang yang merawatnya, yang mengingat masalah kesehatannya, sementara sisanya $35 \%$ hidup sendiri.

Menurut Mubarak, Santoso, Rozikin\& Patonah (2006) alasan lansia perlu dirawat dilingkungan keluarga dikarenakan tempat tinggal keluarga merupakan lingkungan atau tempat alamiah dan damai bagi lansia, selain itu keluarga merupakan pengambil keputusan yang terkait dengan kesehatan anggota keluarganya termasuk lansia, dan masih banyak alasan lainnya mengapa lansia perlu dirawat dilingkungan keluarga.

Keluarga merupakan kunci utama bagi kesehatan serta perilaku sehat sakit, oleh karena itu keluarga terlibat langsung dalam mengambil keputusan dan terapeutik pada setiap tahap sehat- sakit anggota keluarga (Setiadi, 2008). Menurut Friedman (2003) dalam Mubarak, Chayatin, \& Santoso, (2010) fungsi utama keluarga diantaranya adalah fungsi afektif, fungsi sosialisasi, fungsi ekonomi dan fungsi perawatan keluarga. Fungsi utama keluarga salah satu diantaranya adalah fungsi perawatan keluarga, dimana keluarga memberikan perawatan kesehatan yang bersifat preventif dan secara bersama-sama merawat anggota keluarga yang sakit. Kesanggupan keluarga melaksanakan perawatan atau pemeliharaan kesehatan dapat dilihat dari tugas kesehatan keluarga yang dilaksanakan (Mubarak, Chayatin, \& Santoso, 2010).

Lansia dengan penyakit hipertensi memerlukan keluarga dalam melaksanakan tugas kesehatan keluarga. Menurut Setiadi (2008) adapun beberapa hal yang berkaitan dengan tugas kesehatan keluarga meliputi kemampuan untuk mengenal masalah, kemampuan keluarga untuk mengambil keputusan, kemampuan keluarga untuk merawat anggota keluarga yang sakit, kemampuan keluarga dalam memodifikasi lingkungan dan kemampuan keluarga dalam memanfaatkan fasilitas pelayanan kesehatan yang ada (Setiadi, 2008).

Berdasarkan penelitian yang dilakukan oleh Imanah (2012) tentang hubungan lima tugas kesehatan keluarga dengan pencegahan kekambuhan pada klien skizofrenia yang berkunjung di poli jiwa rumah sakit jiwa Menur Surabaya, didapatkan hasil hubungan yang signifikan antara pelaksanaan lima tugas kesehatan keluarga terhadap upaya pencegahan kekambuhan. Hasil ini menunjukkan bahwa keluarga merupakan support utama dalam memenuhi kesehatan anggota keluarganya. Semakin keluarga memahami mengenai pelaksanaan tugas kesehatan keluarga 
maka penyakit yang dialami anggota keluarga dapat diatasi.

Berdasarkan wawancara lansung yang dilakukan terhadap 8 orang keluarga yang memiliki lansia, didapatkan 6 orang keluarga yang memiliki lansia dengan hipertensi diantaranya belum mampu mengenal masalah kesehatan yang terjadi pada lansia, keluarga belum mampu mengambil keputusan apabila lansia mengalami hipertensi, keluarga belum mampu merawat lansia pada saat sakit dengan baik, keluarga belum mampu memodifikasi dan perbaikan lingkungan, dan didapatkan 2 keluarga yang memiliki lansia dengan penyakit hipertensi mengatakan jarang pergi ke pelayanan kesehatan dan belum memahami tugas kesehatan keluarga dengan benar.

Berdasarkan fenomena tersebut, peneliti tertarik untuk melakukan penelitian tentang tugas kesehatan keluarga secara umum dengan judul gambaran pelaksanaan tugas kesehatan keluarga yang memiliki lansia dengan penyakit hipertensi di desa Glagahwero Kecamatan Panti Jember.

\section{METODE}

Penelitian ini menggunakan desain pre eksperimen dengan menggunakan pendekatan One Group Pre-Test Design. Populasi dalam penelitian ini adalah keluarga yang memiliki lansia di Desa Glagahwero yang berusia 60-80 tahun yang berjumlah 8 orang yang menjadi klien kelolaan mahasiswa program studi profesi ners angkatan XX fakultas keperawatan universitas Jember.
Penarikan sampel dilakukan pada keluarga yang memiliki lansia dengan kriteria inklusi keluarga yang memiliki lansia yang menjadi klien kelolaan mahasiswa program studi profesi ners angkatan XX di desa Glagahwero, bersedia menjadi responden.

Penelitian dilakukan di Desa Glagahwero Kecamatan Panti Kabupaten Jember, dilaksanakan pada bulan Mei 2018 sampai Juni 2018. Alat pengumpul data yang digunakan berupa angket.

\section{HASIL}

Tabel 1. Distribusi frekuensi karakteristik responden

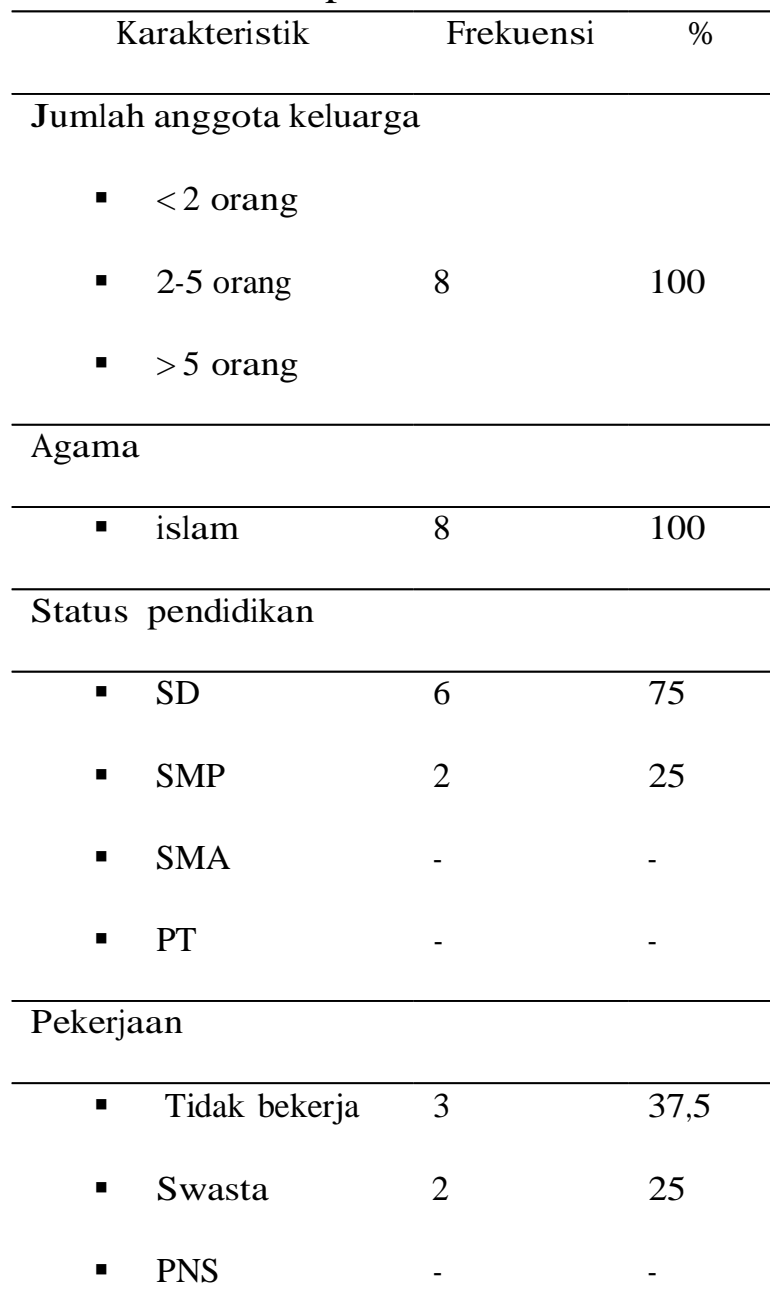


- Pedagang 12,5

- Dll

2

25

Total

100

\section{Berdasarkan tabel 1 diketahui}

data bahwa dari 8 responden yang diteliti, karakteristik

berdasarkan jumlah anggota keluarga seluruh responden dengan jumlah anggota

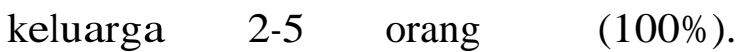
Berdasarkan agama seluruh responden beragama islam (100\%). Karakteristik responden berdasarkan status pendidikan terbanyak adalah tingkat pendidikan SD sebanyak 6 responden (75\%), dan karakteristik berdasarkan pekerjaan mayoritas responden tidak bekerja sebanyak 3 responden $(37,5 \%)$.

Tabel 2. Distribusi frekuensi kemampuan keluarga mengenal masalah hipertensi pada lansia

\begin{tabular}{ccc} 
pada lansia & & \\
\hline mengenal & frekuensi & $\%$ \\
Tinggi & 7 & 87,5 \\
Rendah & 1 & 12,5 \\
Total & 8 & 100
\end{tabular}

Berdasarkan tabel 2 diketahui bahwa dari 8 responden yang diteliti, mayoritas kemampuan responden dalam mengenal masalah hipertensi pada lansia adalah tinggi sebanyak 7 responden $(87,5 \%)$.

Tabel 3. Distribusi frekuensi kemampuan keluarga mengambil keputusn dalam melakukan tindakan perawatan pada lansia

\begin{tabular}{ccc}
\hline Memutuskan & frekuensi & $\%$ \\
\hline Tinggi & 6 & 75
\end{tabular}

$\begin{array}{lcc}\text { Rendah } & 2 & 25 \\ \text { Total } & 8 & 100\end{array}$

Berdasarkan tabel 3 diketehui bahwa dari 8 responden yang diteliti, mayoritas kemampuan keluarga mengambil keputusan dalam melakukan tindakan perawatan pada lansia adalah tinggi sebanyak 6 responden $(75 \%)$.

Tabel 4. Distribusi frekuensi kemampuan keluarga merawat lansia hipertensi

Merawat frekuensi $\%$

$\begin{array}{ccc}\text { Tinggi } & 5 & 62,5 \\ \text { Rendah } & 3 & 37,5 \\ \text { Total } & 8 & 100\end{array}$

Berdasarkan tabel 4 diketahui bawha data dari 8 responden yang diteliti, mayoritas kemampuan keluarga merawat lansia yang mengalami hipertensi adalah tinggi sebanyak 5 responden $(62,5 \%)$.

Tabel 5. Distribusi frekuensi kemampuan keluarga memodifikasi lingkungan $\frac{\text { kesehata sekitar keluarga }}{\text { Memodifikasi frekuensi } \%}$

$\begin{array}{ccc}\text { Tinggi } & 2 & 25 \\ \text { Rendah } & 6 & 75 \\ \text { Total } & 8 & 100\end{array}$

Berdasarkan tabel 5 diketahui bahwa data dari 8 responden yang diteliti, mayoritas kemampuan keluarga memodifikasi lingkungan kesehatan sekitar keluarga rendah sebanyak 6 orang $(75 \%)$. 
Tabel 6. Distribusi frekuensi kemampuan keluarga memanfaatkan fasilitas pelayanan kesehatan yang ada

\begin{tabular}{ccc} 
Memanfaatkan & frekuensi & $\%$ \\
\hline Tinggi & 5 & 62,5 \\
Rendah & 3 & 37,5 \\
Total & 8 & 100
\end{tabular}

Berdasarkan tabel 6 diketahui bahwa data dari 8 responden yang diteiliti, mayoritas kemampuan keluarga memanfaatan fasilitas pelayanan kesehatan yang ada adalah tinggi sebanyak 5 responden $(62,5 \%)$.

Tabel 7. Distribusi frekuensi kemampuan keluarga tentang pelaksanaan tugas kesehatan keluarga yang memiliki lansia dengan penyakit hipertensi

$\begin{array}{ccc}\text { Pelaksanaan } & \text { frekuensi } & \% \\ \text { Tinggi } & 5 & 62,5 \\ \text { Rendah } & 3 & 37,5 \\ \text { Total } & 8 & 100\end{array}$

\section{Berdasarkan tabel 7 diketahui}

bahwa dari 8 responden yang diteliti, mayoritas kemampuan keluarga tentang pelaksanaan tugas kesehatan keluarga yang memiliki lansia dengan masalah hipertensi adalah tinggi sebanyak 5 responden $(62,5 \%)$.

\section{PEMBAHASAN}

\section{Karakteristik responden}

Dari hasil penelitian tentang karakteristik responden ditemukan bahwa karateristik berdasarkan jumlah anggota keluarga mayoritas dengan jumlah anggota keluarga 2-5 orang sebanyak 8 responden (100\%). Berdasarkan agama seluruh responden beragama islam (100\%), karateristik responden berdasarkan status pendidikan yang terbanyak adalah tingkat pendidikan SD yang berjumlah 6 responden $(75 \%)$ dan karateristik responden berdasarkan pekerjaan yang terbanyak adalah tidak bekerja yang berjumlah 3 responden (37,5\%). Menurut Friedman (2005) mendefinisikan bahwa keluarga adalah kumpulan dua orang atau lebih yang hidup bersama dengan keterikatan aturan dan emosional dan individu mempunyai peran masing-masing yang merupakan bagian dari keluarga. Keluarga merupakan salah satu unsur yang berperan penting dalam proses pelayanan kesehatan pada anggota keluarga. Jumlah anggota keluarga akan sangat mempengaruhi terhadap perhatian dan fokus pelayanan pada anggota keluarga. Keluarga yang memiliki jumlah anggota keluarga yang lebih banyak akan menyebabkan menurunnya perhatian kepada anggota keluarga yang mengalami masalah-masalah didalam keluarga. Selain itu juga besar kecilnya keluarga akan sangat mempengaruhi pendapatan rumah tangga karena besarnya biaya yang dikeluarkan untuk memenuhi konsumsi rumah tangga lebih banyak sehingga dituntut pemasukan yang lebih tinggi. Pengeluaran yang dikeluarkan biasanya hanya sebatas memenuhi kebutuhan pokok saja. Belum lagi memperhitungkan kebutuhan lain yang jarang diperhitungkan dengan biaya seperti konsumsi air sehari-hari. Berdasarkan hasil dari peneliti menunjukkan jumlah anggota keluarga 2- 5 orang mempengaruhi perhatian dan fokus pelayanan terhadap lansia 
yang menderita hipertensi, perhatian dan fokus pelayanan dapat diberikan keluarga dengan baik terhadap lansia.

Unsur karakteristik yang
berperan penting dalam pelaksanaan tugas kesehatan keluarga salah satunya adalah pendidikan, merupakan faktor yang mempengaruhi pola pikir seseorang. Menurut Perry \& Potter (2005) latar belakang pendidikan akan membentuk cara berpikir seseorang termasuk membentuk kemampuan untuk memahami faktor-faktor yang berkaitan dengan penyakit dan menggunakan pengetahuan tersebut untuk menjaga kesehatan.

Hal ini sejalan dengan penelitian yang telah dilakukan oleh Sugiharto, Suharyo, Sukandarno, dan Shofa (2003), dimana pada penelitian yang dilakukan terhadap 310 pasien hipertensi didapatkan tingkat pendidikan responden paling banyak yaitu tidak pernah sekolah sebanyak 48 orang (31\%), pendidikan responden paling sedikit adalah tamat akademi sebanyak 1 orang $(0,6 \%)$ dan tamat pasca sarjana sebanyak 1 orang $(0,6 \%)$. Penelitian tersebut menyimpulkan bahwa tingkat pendidikan dapat mempengaruhi kemampuan dan pengetahuan seseorang dalam menerapkan perilaku hidup sehat. Semakin tinggi tingkat pendidikan maka semakin tinggi kemampuan seseorang dalam menjaga kesehatan.

\section{Kemampuan Keluarga Dalam \\ Pelaksanaan Tugas Kesehatan Keluarga Yang Memiliki Lansia Dengan Penyakit Hipertensi}

Hasil penelitian menunjukkan
bahwa mayoritas

keluarga tentang pelaksanaan tugas kesehatan keluarga yang memiliki lansia dengan penyakit hipertensi adalah tinggi sebanyak 5 responden $(62,5 \%)$. Bila dilihat dari tugas kesehatan keluarga berdasarkan mengenal masalah kesehatan mayoritas adalah kategori tinggi yaitu sebesar 7 responden (87,5\%). Kemampuan seseorang dipengaruhi oleh beberapa faktor antara lain pendidikan yang diterima, semakin tinggi tingkat pendidikan seseorang maka semakin baik pula tingkat pengetahuannya. Hal ini juga didukung oleh Notoatmodjo (2005) yang mengemukakan bahwa pendidikan merupakan perubahan pada diri manusia sehingga pendidikan merupakan salah satu faktor yang dapat mempengaruhi persepsi seseorang lebih mudah dalam mengambil keputusan dan bertindak.

Menurut Setiadi

(2008) mengenal masalah kesehatan keluarga yaitu sejauh mana keluarga, mengenal fakta-fakta dari masalah kesehatan keluarga yang meliputi pengertian, tanda dan gejala, penyebab dan yang mempengaruhi serta persepsi keluarga terhadap masalah. Pelaksanaan tugas kesehatan keluarga terhadap lansia dengan hipertensi, menunjukkan kemampuan keluarga dalam mengenal gejala hipertensi yang sering dialami lansia seperti sakit kepala, gelisah, nyeri tengkuk, mual, dan muntah, sesak nafas, dan pandangan menjadi kabur. Keluarga mengetahui faktor-faktor penyebab hipertensi seperti merokok dan mengkonsumsi garam yang berlebihan. Kemampuan keluarga 
dalam mengenal masalah hipertensi pada lansia sangat berperan penting dalam upaya peningkatan kesehatan lansia, sehingga beban keluarga dalam mengurus lansia dapat berkurang.

Berdasarkan tugas kesehatan keluarga yang kedua yaitu mengambil keputusan didapatkan hasil bahwa mayoritas kemampuan keluarga dalam mengambil keputusan adalah tinggi sebanyak 6 responden (75\%). Keluarga merupakan kunci utama bagi kesehatan serta perilaku sehat sakit, oleh karena itu keluarga terlibat lansung dalam mengambil keputusan dan terapeutik pada setiap tahap sehat -sakit anggota keluarga (Setiadi, 2008). Mengambil sebuah keputusan kesehatan keluarga merupakan langkah sejauh mana keluarga mengerti mengenai sifat dan luasnya masalah, apakah masalah dirasakan, menyerah terhadap masalah yang dihadapi, takut akan akibat tindakan penyakit, mempunyai sikap negatif terhadap masalah kesehatan. Kemampuan keluarga dalam mengambil keputusan terhadap lansia dengan hipertensi mengerti akan dampak dari hipertensi seperti stroke, kerusakan ginjal, penyakit jantung, dan gangguan penglihatan. Keluarga memberi saran kepada lansia untuk segara memberi tahu keluarga jika gejala hipertensi muncul/ dialami oleh lansia.

Berdasarkan tugas kesehatan keluarga dalam merawat lansia didapatkan hasil bahwa mayoritas kemampuan keluarga merawat lansia yang mengalami hipertensi adalah tinggi sebanyak 5 responden $(62,5 \%)$.
Fungsi utama keluarga salah satu diantaranya adalah fungsi perawatan keluarga, dimana keluarga memberikan perawatan kesehatan yang bersifat preventif dan secara bersama-sama merawat anggota keluarga yang sakit. Kesanggupan keluarga melaksanakan perawatan atau pemeliharaan kesehatan dapat dilihat dari tugas kesehatan keluarga yang dilaksanakan (Mubarak, Chayatin, \& Santoso, 2010).

Menurut Setiadi, (2008) anggota keluarga dalam menjalankan fungsinya perlu mengetahui keadaan penyakitnya, mengetahui sifat dan perkembangan perawatan yang dibutuhkan, mengetahui sumber-sumber yang ada dalam keluarga (anggota keluarga yang bertanggung jawab, keuangan, fasilitas fisik, psikososial), mengetahui keberadaan fasilitas yang diperlukan untuk perawatan dan sikap keluarga terhadap yang sakit. Perawatan keluarga dengan melakukan perawatan sederhana sesuai dengan kemampuan, dimana perawatan keluarga yang biasa dilakukan dan cara pencegahannya seminimial mungkin. Keluarga memberikan perawatan kesehatan yang bersifat preventif dan secara bersama-sama merawat anggota keluarga yang sakit. (Setiadi, 2008). Keluarga dalam merawat lansia dengan hipertensi menujukkan memenuhi kebutuhan saat lansia sakit, membatasi aktivitas yang melelahkan dan membatasi pola makan lansia seperti mengurangi penggunaan garam dalam masakan. Pemahaman dalam proses pelaksanaan perawatan keluarga sangat diperlukan, sehingga keluarga 
mampu melaksanakan kegiatankegiatan selama proses perawatan lansia baik sebelum ataupun sesudah mengalami hipertensi.

Berdasarkan tugas kesehatan keluarga dalam memodifikasi lingkungan didapatkan hasil kemampuan keluarga memodifikasi lingkungan kesehatan sekitar keluarga adalah rendah sebanyak 6 responden (75\%). Menurut Setiadi (2008), modifikasi lingkungan sejauh mana keluarga mengetahui sumber-sumber keluarga yang dimiliki, keuntungan/manfaat pemeliharaan lingkungan, mengetahui pentingnya hygiene sanitasi dan kekompakan antar anggota keluarga.

Memodifikasi lingkungan dapat membantu dalam melakukan perawatan pada anggota keluarga yang mengalami masalah kesehatan, dalam bentuk kebersihan rumah dan menciptakan kenyamanan agar dapat beristirahat dengan tenang tanpa adanya gangguan dari luar. Selain itu perbaikan dan pemeliharaan kesehatan sangat perlu terutama melalui komitmen dan modifikasi lingkungan serta gaya hidup pribadi, hal ini semakin memperkuat peran pokok keluarga dalam melaksanakan tanggung jawab terhadap kesehatan para anggotanya.

\section{Lansia yang mengalami} penyakit kronis seperti hipertensi pada umumnya lebih memilih tinggal dilingkungan keluarga. Menurut Tamher \& Noorkasiani (2011) keluarga merupakan tempat berlindung yang paling disukai para lansia. Lansia lebih memilih tinggal bersama keluarganya dari pada tinggal di institusi seperti panti jompo, terdapat sekitar 65\% lansia yang mengidap gangguan kesehatan seperti penyakit kronik atau kecacatan, hidup bersama orang yang merawatnya, yang mengingat masalah kesehatannya, sementara sisanya $35 \%$ hidup sendiri.

Hasil penelitian menunjukkan modifikasi lingkungan keluarga dengan lansia hipertensi mampu berperilaku menyenangkan dirumah agar tidak terjadi stress, dimana stress yang dialami lansia bila berkelanjutan memicu terjadinya hipertensi, Modifikasi dilakukan agar lingkungan keluarga menjadi lingkungan yang nyaman dan damai bagi lansia.

Berdasarkan tugas kesehatan keluarga dalam memanfaatkan fasilitas kesehatan adalah mayoritas tinggi sebanyak sebanyak 5 responden (62,5\%). Menurut Setiadi (2008) kemampuan keluarga memanfaatkan fasilitas pelayanan kesehatan dimana keluarga mengetahui apakah keberadaan fasilitas kesehatan, memahami keuntungan yang diperoleh dari fisilitas kesehatan, tingkat kepercayaan keluarga terhadap petugas kesehatan dan fasilitas kesehatan tersebut terjangkau oleh keluarga.

Keluarga dalam memanfaatkan pelayanan kesehatan, dimana biasa mengunjungi pelayanan kesehatan yang biasa dikunjungi dan cenderung yang paling dekat misalnya posyandu, Puskesmas maupun rumah sakit, hal ini dilakukan dengan alasan lebih efisien waktu dan merasa cocok.

Menurut penelitian yang 
dilakukan oleh Amelia (2012) tentang hubungan antara tugas kesehatan keluarga dengan kejadian stroke berulang pada lansia di Wilayah Kerja Puskesmas Lubuk Buaya Padang. Didapatkan hasil tidak ada hubungan bermakna antara tugas kesehatan keluarga dengan kejadian stroke berulang. Sebanyak 27 keluarga dari 31 Keluarga mampu mengenal masalah, dari 19 keluarga mampu mengambil keputusan, 25 keluarga mampu memberikan perawatan, 20 keluarga mampu memodifikasi lingkungan dan sebanyak 30 dari 31 keluarga mampu memanfaatkan fasilitas kesehatan dengan baik.

Keluarga dalam memanfaatkan fasilitas kesehatan harus mampu memanfaatkan fasilitasfasilitas kesehatan yang ada di masyarakat seperti Puskesmas dan posyandu untuk lansia agar kesehatan pada lansia dengan hipertensi dapat terkontrol. Sering kali kemampuan keluarga untuk menjangkau fasilitas kesehatan menjadi kendala bagi keluarga untuk membawa lansia ke fasilitas kesehatan. Keluarga yang memeliki lansia dengan hipertensi mendapatkan informasi tentang penanganan penyakit dan rajin mengontrol tekanan darah ke pelayanan tedekat seperti Puskesmas.

Kemampuan keluarga dalam pelaksanaan tugas kesehatan keluarga tinggi dikarenakan faktor pendidikan responden, sehingga mudah menyerap informasi-informasi terbaru khususnya mengenai penyakit hipertensi, pengetahuan responden yang sudah banyak tentang hipertensi, memanfaatkan fasilitas kesehatan yang terjangkau berada di perkotaan mempermudah keluarga mengambil keputusan yang tepat dan semaksimal mungkin memanfaatkan fasilitasfasilitas kesehatan seperti penyuluhan khususnya tentang penyakit hipertensi yang dialami lansia.

\section{KESIMPULAN}

Dari hasil penelitian yang dilakukan tentang gambaran pelaksanaan tugas kesehatan keluarga yang memiliki lansia dengan penyakit hipertensi di desa Glagahwero Kecamatan Panti Kabupaten Jember, dapat disimpulkan sebagai berikut: mayoritas kemampuan keluarga tentang pelaksanaan tugas kesehatan keluarga yang memiliki lansia dengan hipertensi adalah tinggi (62,5\%), mayoritas kemampuan keluarga dalam mengenal masalah hipertensi pada lansia adalah tinggi $(87,5 \%)$, mayoritas kemampuan keluarga mengambil keputusan dalam melakukan tindakan perawatan pada lansia adalah tinggi (75\%), mayoritas kemampuan keluarga merawat lansia yang mengalami hipertensi adalah tinggi (62,5\%),Mayoritas kemampuan keluarga memodifikasi lingkungan kesehatan sekitar keluarga adalah rendah (75\%), mayoritas kemampuan keluarga memanfaatkan fasilitas pelayanan kesehatan yang ada adalah tinggi $(62,5 \%)$. 


\section{SARAN}

Berdasarkan hasil kesimpulan diatas maka dapat diberikan beberapa saran yang ditujukan pada keluarga dan Tenaga Kesehatan Di Puskesmas dan Instansi Kesehatan Lainnya sebagai berikut:

1. Kepada keluarga Mempunyai Lansia

Diharapakan kepada keluarga untuk dapat membawa lansia ke Puskesmas atau posyandu tiap bulannya agar kesehatan lansia dapat terkontrol dan diharapkan keluarga selalu mencari informasi yang berhubungan dengan tugas- tugas keluarga dalam merawat lansia dengan hipertensi.

\section{Kepada Pendidikan Keperawatan}

Diharapkan hasil penelitian ini dapat manjadi referensi bagi mahasiswa keperawatan sehingga menambah wawasan tentang pelaksanaan tugas kesehatan keluarga yang memiliki lansia dengan penyakit hipertensi.

\section{Kepada Pihak Puskesmas}

Diharapkan kepada puskesmas untuk dapat melakukan Peningkatan upaya penyuluhan kepada masyarakat terutama keluarga yang memiliki lansia tentang pentingnya upaya peningkatan derajat kesehatan lansia dan perawatan pada lansia dengan hipertensi, dan cara memodifikasi lingkungan karena berdasarkan hasil penelitian dalam distribusi frekuensi keluarga memodifikasi lingkungan mayoritas rendah. Selain itu perlu dilakukanya upaya kerjasama dengan lintas sektor maupun lintas program dalam peningkatan komunikasi, informasi dan motivasi dalam pemberian edukasi pada masyarakat /keluarga lansia.

\section{Bagi Peneliti selanjutnya}

Diharapkan hasil penelitian ini dapat digunakan sebagai dasar untuk penelitian lebih lanjut terkait pelaksanaan tugas kesehatan keluarga yang memiliki lansia dengan variabel- variabel yang lain.

\section{KEPUSTAKAAN}

Adib, M. 2009. Cara mudah memahami dan menghindari hipertensi, jantung, dan stroke. Yogyakarta: Dianloka.

Anggaraeni, Y. 2012. Super komplet pengobatan darah tinggi. Yogyakarta: Araska.

Fatimah, 2010. Merawat manusia lanjut usia. Jakarta: Trans info media.

Friedman, M.M., Bowden, V.R., \& Jones, E.G. 2003. Family nursing, research, theory and practice. New Jersey: Prentice Hall.

Friedman. 2005. Keperawatan keluarga. Edisi 3. Jakarta: EGC

Kemenkes RI, 2013. Gambaran kesehatan lansia di Indonesia.

Martono, 2011. Lanjut usia dan dampak sistemik dalam siklus kehidupan.

Maryam, R.S., Ekasari, M.F., Rosidawati., Jubaedi, A., \& Batubara, I. 2008. Mengenal usia lanjut danperawatannya. Jakarta: Salemba Medika.

Mubarak, W.I., Chayatin, N., \& Santoso, B.A. 2010. Ilmu keperawatan komunitas konsep dan aplikasi. Jakarta: Selemba Medika. 